\title{
Building Fiqh Education to De-Radicalization
}

\author{
Hasbiyallah, Erni Haryanti \\ UIN Sunan Gunung Djati Bandung, Jl. AH. Nasution No. 105, Bandung, Indonesia \\ Corresponding e-mail: erni_hk@uinsgd.ac.id
}

\begin{abstract}
This article aims at building Fiqh (Islamic Jurisprudence) from which Islamic education system would be operating to de-radicalization. As the study of the Shari'ah (Islamic Law and rules), the whole corpus of Figh is about the interpretation of the Holy Qur'an and the Sunnah (the practice and tradition of Muhammad PBUH) through the process of independent reasoning (Ijtihad) carried out by qualified Islamic scholar/s (ulama). Therefore, this study begins to consider the overall operation of formulating Islamic Law that should become the purpose of Allah and His Messenger. Meanwhile, the way achieving Islamic Law, among other things, is oriented to produce mashlahah (wisdom) for making better and improving the prosperity of the ummah both in the world and Hereafter. For this reason, the task of ulama is to comprehend the Muslim society and related things entail to contemporary life demands. Although thinking much more thoroughly, Ulama's independent reasoning results in diversity. Thus, Fiqh is dynamic; supporters of certain ulama with certain Fiqh schools are those who are fanatical. Through the efforts of education, such extremism and radicalism can be reduced (applied to de-radicalization) through the Fiqh itself. In Fiqh education, a curriculum that includes selected and non-selected teaching materials play an essential role likewise educators who organize schools instructions. It should remove religious extremism including fanaticism, intolerance, rigidity, and narrow-mindedness gradually. Fiqh materials provided at Islamic schools should aim at attaining mashlahah through which peace, unity, justice, equality, and capacity. It should able to suppress all kinds of violence, and order would flower among students participants of Islamic schools.
\end{abstract}

Keywords: Indonesian Islam, Contemporary Fiqh, Islamic Education, Radicalization, De-radicalization

\section{INTRODUCTION}

Recently, phenomena of radicalization among people of several countries have been escalating. Early recognition refers to the effect of the 9/11 attacks in New York City. Since then, the terrors have not stopped; it even spread too in many countries, such as Iraq, Pakistan, Afghanistan, Thailand, Russia, and the Philippines. In Indonesia, the world's largest Muslim-majority nation with its religious diversity, although it proves living in harmony (Bachtiar, 2013), also radicalization also continue existing. In those countries, terrorism and radicalism have in fact been endorsed by a small but forceful group of people, leaving other more massive Muslims to take responsibility as anti-terror guards. Towards such escalation of terrorism and radicalization, so many works have been carried out, among other things have been done by Spalek and Lambert (2008). They explore how and the ways Muslim communities can engage to counter- terrorism and counter-radicalism. Meanwhile, Dechesne (2011) writes to review de-radicalization programs, examining how to change behaviour not thoughts, to find motives people to de-radicalize, and to increase the effectiveness of de-radicalization. Furthermore, Doosje et al. (2016) present a similar model of radicalization process to de-radicalization one. Both methods of Dechesne and Doosje et al. highlight the importance of the role of group membership and intergroup relations.

This study does not endorse violence and terrorism associated with Muslims in general, instead, it focuses on de-radicalization experiencing among Muslim traditions, i.e., understanding Fiqh in the way of its implementation among different followers of certain Islamic scholar schools. It does not discuss tolerance alone, but building respectful dialogues through understanding various Fiqh schools in Islamic educational institutions can unite Indonesian diversities. As a result, correct 
understanding can replace the distorted images of Muslims' radicalism to peace.

Finally, this study would explore Fiqh in the way it develops at Islamic education institutions. It reveals how different Fiqh inclusion in curriculum and educators can implement it at classroom activities. The building of Fiqh education should aim at dissemination of Islamic science that can answer a practical matter and paramount to the construction of Islamic wisdom for all societies.

\section{METHODOLOGY}

Muslim social scientists are encouraged to learn source methodology developed by Islamic scholars of al Usul Fiqh (Alalwani, 1990). Its importance is highlighted to be its solid foundation for the basis of all the Islamic disciplines; it is a study dealing with and interpreting al-Qur'anic texts and Sunnah. Furthermore, Zahraa (2003) divides two distinct major fields of research which have emerged since the end of Companions' Age known as (1) Islamic Science of methodology (Ushul al-Fiqh), and (2) detailed answers to the practical matters of Islamic Law (al masail wa al furu). This study lays its foundation on Islamic values. Accordingly, it should embrace essential elements: (1) Qur'an (the Holy Book). (2) Sunnah (the Prophet Muhammad tradition). Finally, (3) Ijtihad (Independent Islamic reasonings of certain ulama) which later development consisting Ijma (consensus of Islamic scholars and jurists) and Qiyas (deduction of Islamic legal prescriptions based on analogic reasoning). Recently, there have also been Istihsan (a distinctive methodology used by only several ulama) and Maslahah Mursalah (an act consisting of ethical values or advantages).

Furthermore, Fiqh as a discipline with its central design of finding a particular thing is permissible or prohibited; it consists of normative statements of Qur'an and Sunnah which relate to human behaviour together with the rights and obligations. In this case, Ijtihad as one of the primary sources of Islamic values influences many authoritative legal opinions produced by certain Islamic scholars. This legal advice can decide a thing whether or not a Muslim individual would be admitted to be obligatory (wajib), recommended (mundub), permissible (mubah), abominable (makruh) and prohibited (haram) (Saleem, 2010). In their legal opinions, Islamic scholars would be different from one to another due to various individuals, time, places, and regions. These differences are reasons for the followers of each Islamic scholar cannot be fanatical; instead, they need to understand each other. Finally, to build mutual understanding among Muslim followers of different Fiqh schools is through a comprehensive education.

Auda (2008) reiterates Al-Qaradhawi Fiqh saying that someone must prioritize the important and then the most important over the unimportant thing; the major over the minor which means that someone must put first things first and last words last. Al-Qaradhawi (1998) himself argues that Priority Fiqh has laid his distinctive Fiqh in a matter of deciding everything in its actual order, placing a hierarchy of rules, values, or action, based on justice. This priority Fiqh has a healthy relationship with objectives Fiqh, textual Fiqh, and Balance Fiqh (Ismail, 2009). Meanwhile, Auda's scholarship is about Qur'an and Sunnah for the guidance of human being that is the highlight of Maqashid Syari'ah (MS), higher purposes and intents that should be achieved by Islamic Law, among other things through Fiqh. MS can explain how wisdom entails to rulings. For example, understanding behind charity is to enhance social cohesion.

\section{RESULTS AND DISCUSSION}

De-radicalization of Fiqh Education is much essential to the effort of eliminating exclusivism of Muslim people. Fiqh education has been considered to be failing in shaping learners' tolerance and moderation. It is due to Fiqh has sympathetic characters for social change and deemed to be able to accommodate the changing socio-cultural aspects that should be understood both literal and contextual situation. Islamic Jurisprudence with its elasticity can provide adequate space for the possibility of legal changes from time to time and place to place. This strategic function of Fiqh can work well where the role of Fiqh education plays a role in the efforts of de-radicalization. Thus, every learner of an Islamic institution should understand the opinions of others differently due to the difference of time, place or condition. So there is no need to be coercion to other legal ideas, and making the justification to their own opinions for blaming other ideas.

De-radicalization through Fiqh education implements minimum two things: curriculum and educators.

\subsection{Fiqh Curriculum}

After passing the curriculum that affirms to meet intelligence in learners' possession, then, it would create learners' competence. Students gain their 
capability colored and supported by universal spiritual values derived from Islamic values. Moral and religious attitudes are the basis of the belief that the spiritual potential of the human being is controlling a series of destructive radical measures which could threaten and harmful the society. Religious, moral attitude mean that the ability to give meaning to their knowledge and skills through a learning process that emphasizes exploration and problem-solving. Learners face the problem with no single solution openly, and the problem with the various ways completions.

Fiqh curriculum should have tolerance dimension, an outstanding idea. Today, the escalation of violence on behalf of religion (ideology sect) is increasing. The existence of Figh curriculum with tolerance becomes a critical component; a guide for educators in delivering materials about Islam that respects the similarity and diversity.

Therefore, Fiqh curriculum has to prepare learners at the earliest time. Learners have to learn and get familiar not only with the normative, doctrinal, and deductive subjects at which there has not the only relation with the cultural context, but they must be taught by historical-empirical-inductive matters as well. This situation indicates that Fiqh curriculum needs to compare between the subject in the form of text and context. The text means here should consist of normative teachings which are still common when the context is always factual, an empirical reality which has a particular term. Issues often exist when the text is dealing with the facts of the various particular. Therefore, the study of Fiqh subject at Islamic schools should refer to real social practices faced by learners in daily life. Besides, although the assigned materials consist of normative texts, also it must see to actual case studies in a social community so that children are aware that they are living in a real situation of diverse cultures (multicultural background).

Other characteristics of a multicultural curriculum show as follows: (a) creation of "human culture" and creation of a "civilized society" (cultured). (b) building excellent values of humanity, the nations, and ethnic groups (cultural). (c) including democratic values, which appreciate aspects of cultural differences and diversity of nationalities and ethnic groups (multicultural). (e) assessment of the students' behavior covering perception, appreciation, and action against other cultures.

As argued above, Fiqh curriculum builds both learners' development dimension and the values of multicultural education in a religious scholar sect paradigm. There are the components of the curriculum of multicultural Fiqh education as follows; the study of a scholar sect paradigm, a group of scholar Fiqh minority, the awareness of broader scholar community culture, the relationship among Fiqh scholars, and clarifying the values in a Fiqh scholar culture. Those components and the concepts that include racism, justice, discrimination, distinction, and others are the parts of Fiqh curriculum.

Fiqh education integrates with the spirit of multicultural Fiqh needs to introduce the tolerant Islamic teachings with the emphasis on understanding and effort to be able to live in the context of diversity schools, religions, and cultures, whether individual aspect or groups. Therefore, in the development of multicultural education curriculum should be considered the following dimensions:

First, learning Fiqh should consider the muqaran approach (comparison). It is crucial because students study about both the knowledge and understanding of the Islamic legal law in Fiqh and about a different view of the scholar schools. They do not just know the diversity but even given the knowledge (argument-proof) why it can happen.

Second, to improve social intelligence, learners should receive scholarly education and also interreligious borders. This improvement can be carried out by holding a dialogue between different Fiqh scholar schools and religions;

Third, to see the reality of the diversity in Fiqh scholar schools, institutions of Islamic education organizes a road show program across Fiqh scholar schools; it is to achieve a goal of community awareness and solidarity towards other Fiqh scholar schools.

Fourth, to create spiritual awareness, Islamic education needs to hold activities, such as religious work camp. These Islamic education activities in its implementation are first to send learners to stay in a particular family for several days; a possible stay is in different Fiqh scholar schools. During these activities, learners have to communicate and perform daily programs outside houses as well as inside their stayed family. By achieving the goal, this program is to create awareness and sensitivity of learners to appreciate and respect the other Fiqh scholar schools.

In the process of de-radicalization through Fiqh education, some parts of the curriculum together can develop aspects of multicultural Fiqh, as follows:

First, the essence of Fiqh is the Fiqh mentioned in al-Quran interpreted in-depth understanding. This Islamic Jurisprudence can be a skeptical term. Sceptic Figh proves the perspective of Islamic scholars in the majority that specify that the Fiqh products are a temporary argument (zhanni). The character of temporary Fiqh (zhanni) influences the capacity of the truth. The nature of skeptical Fiqh 
gives a chance to be reviewed. All Fiqh products are ready to be evaluated. The process of continuous examination on Fiqh products made by Islamic scholars would reveal the historical records in their various Fiqh thinking of a legal act. A Leading Fiqh scholar, such as Imam Shafi'i tried to conduct his internal evaluations on his thought, resulted in bringing a distinctive terminology of the old arguments (qaul qadim) and recent arguments (qaul jadid).

Second, Fiqh reconstruction aims to build a culture of a high civilization based culture. For instance, in the history of the prophet Muhammad PBUH, how he managed and lead the people of Madina in a multi-ethnic, multicultural and multireligious community. The condition of Madina society at that time was not much different from the people of Indonesia, who also were multi-ethnic, multicultural and multi-religious types.

Third, the strengthening on Islamic reasoning methods used the foundation of Fiqh (and Ushul Fiqh) with an agreed methodology likes Qiyas law.

Thus, the Fiqh curriculum has to lay a frame of inclusiveness deriving from the statement of Abdullah (2015) which strengthen contract dimension of religious, social community in religious education (meaning Fiqh). Fiqh Education based multicultural inclusiveness has to move individual morality to public morality; it should aim at giving the God interpretation of metaphysical fantasy concept to landing to and tried to apply the faith (theology) frame and Fiqh decentralization.

\subsection{Fiqh Educators}

Fiqh educators refer to educators who have an essential task in de-radicalization as a whole. A research finding meets Abdullah's (2015) writing that highlights the five primary functions to overcome the religious diversity of Fiqh, thus builds de-radicalization among Muslim learners. Those are: (1) Introducing contemporary issues are to add to the efforts of explaining the teachings of classical Islam. (2) Managing the goal is to solve the problem of human relationships; (3) Contextualizing Islam should be in an appropriate way. (4) Criticizing the suppression of religious education not only focuses on the cognitive domain; (5) Dedicating Islam is not just for the development of individual morality, but also of public morality.

Based on the primary task, Fiqh educators should focus on how to teach about religion (teaching about religion) which involves both historical and comparative approaches. It is crucial to creating students' awareness about the universal aspect and religious teaching particular. Also, it is useful to overcome the lack of attention that emerges recently. There should be an attempt to see a different understanding of other Islamic jurisprudents of scholar schools, other religions, and lack of cultivation of moral values that support interreligious harmony. All these absences may come from the attitude of overprotective. Therefore, the suspicion is still colouring the outlook between the followers of a religious school and Fiqh scholar school.

Fiqh education plays a vital role in implementing the values of diversity inclusive and moderate schools (madrasah). If educators have an understanding of diversity paradigm that is inclusive and moderate, they will also teach and implement the values the diversity of learners in the school. The role of educators in this aspect is as follows: First, an educator must be able to show their democratic behaviour, both attitude and their words are not discriminatory. Secondly, educators should have strong awareness in specific events that had to do with religion. Third, teachers should explain that the essence of the teachings of faith is peace and prosperity for all humankind, so, the bombing, military invasion, and all forms of violence is something that is prohibited by religion. Fourth, educators can provide an understanding of the importance of dialogue and consultation in resolving various issues relating to cultural diversity, ethnicity, and religious streams.

\section{CONCLUSIONS}

Based on the above description, it concludes that (1) the Islamic Jurisprudence curriculum should be introduced at the earliest time to learners. Priority materials that relate to the methodology of Fiqh can be carried out through reasoning methods of Qiyas, Istihsan, Maslahah Mursalah; all of them are oriented to attain Maslahah Ummah (higher advantages for Muslims). Further, Fiqh materials should give in the balance of developing learners as individuals and achieve characters of social piety, synchronizing different Fiqh schools of Nusantara Islam, introducing the products of Islamic scholars and Jurists, and developing road-show programs across various educational institutions. (2) Fiqh educators should act as figures of peace among different Fiqh schools. Therefore, Fiqh educators have to understand every kind of difference of Fiqh schools. Finally, through Fiqh education, religious extremism including fanaticism, intolerance, 
rigidity, and narrow-mindedness can be removed gradually among Muslim learners at Islamic schools.

\section{ACKNOWLEDGEMENTS}

The authors wish to thank UIN Sunan Gunung Djati Bandung.

\section{REFERENCES}

Abdullah, M. A. (2015). Metodologi Fiqh Sosial dari Qauli menuju Manhaji. Purworejo: Staimafa.

Alalwani, T. J., Al-Shikh-Ali, A. S., \& DeLorenzo, Y. T. (2003). Source methodology in Islamic jurisprudence. Herndon, Virginia: International Institute of Islamic Thought (IIIT).

Al-Qaradhawi, Y. (1998). A new figh of priorities. Cairo: Dar al wahb.

Auda, J. (2008). Maqasid Al Shari'ah: an Introductory Guide. London: The International Institute of Islamic Thought (IIIT).

Bachtiar, M. (2013, October 31). The Rising Tide of Radicalism Threatening Indonesia, Retrieved from http://jakartaglobe.id/archive/the-rising-tide-ofradicalism-threatening-indonesia

Dechesne, M. (2011). Deradicalization: not soft, but strategic. Crime, Law and Social Change, 55(4), pp. 287-292.

Doosje, B., et. al. (2016). Terrorism, radicalization and deradicalization. Current Opinion in Psychology, 11, pp. $79-84$.

Hasbiyallah et. al. (2017). Transformation of The Education of Moderate Muslim Society: A Thought Study of Nahdlatul Ulama. Jurnal Pendidikan Islam, 6 (1), pp 25-50.

Ismail, A. (2010). Fiqh aulawiyat in retakaful-Between RBC (Risk Based Capital) Standards and Islamic Institutions. In ISRA Islamic Finance Seminar. Retrieved, 15.

Khallaf, 'AW. (1968). 'Ilm Ushul al-Figh, Kairo: Dakwah Islamiyah Shabab al-Azhar.

Ramadan, T. (2009). Radical reform: Islamic ethics and liberation. Oxford: Oxford University Press.

Saleem, M. Y. (2010). Methods and Methodologies in Fiqh and Islamic Economics. Review of Islamic Economics, 14(1), pp. 103-123.

Spalek, B., \& Lambert, R. (2008). Muslim communities, counter-terrorism and counter-radicalisation: A critically reflective approach to engagement. International Journal of Law, Crime and Justice, 36(4), pp. 257-270.

Zahraa, M. (2003). Unique Islamic law methodology and the validity of modern legal and social science research methods for Islamic research. Arab Law Quarterly, 18(3), pp. 215-249. 